\title{
ARTIGO \\ Breve história do princípio da separação dos poderes nos paradigmas do Estado de direito ${ }^{1}$
}

Cícero José Barbosa Nery Júnior ${ }^{2}$

Como citar este artigo: NERY JÚNIOR, Cícero José Barbosa. Breve história do princípio da separação dos poderes nos paradigmas do Estado de direito. Revista de Ciências do Estado. Belo Horizonte: v. 5, n. 1, e14786. ISSN: 2525-8036.

Resumo: o paradigma do Estado Democrático de Direito, tendo por finalidade a concretização dos direitos previstos na Constituição, confiou ao Poder Judiciário a honorável missão dar efetividade aos direitos constitucionais. Deste modo, a cúpula deste Poder, o STF, tornou-se um dos protagonistas no palco político do Brasil, o que tem levantado discussões doutrinárias e da esfera pública a respeito sobre a sua legitimidade em agir proativamente. Analisar-se-á, através de reconstruções históricas quanto às origens do princípio da Separação dos Poderes e do Estado Democrático de Direito, consagrados pela Constituição de 1988, o risco que a justaposição de um dos Poderes sobre os demais representa para a (re)conquistada democracia nacional.

Palavras-chave: Separação dos Poderes; Estado Democrático de Direito; Justaposição dos Poderes.

\section{INTRODUÇÃO}

Assentada sobre fundações democráticas, coroada com o poder que decorre da vontade popular, a Sexta República Brasileira nasceu sob a forma de um Estado Constitucional

\footnotetext{
${ }^{1}$ Adaptação da monografia apresentada pelo autor como Trabalho de Conclusão de Curso à Banca composta pelos professores Dr. ${ }^{a}$ Renata Camilo de Oliveira (orientadora) e Dr. Carlos José Teixeira de Toledo (examinador). ${ }_{2}$ Advogado. Pós-Graduando em Direito de Família pela Escola Brasileira de Direito - EBRADI, Bacharel em Direito pela Faculdade de Direito da Universidade São Judas Tadeu - USJT. Currículo Lattes: http://lattes.cnpq.br/4979429874971879. E-mail: ciceroneryjr@gmail.com.
} 
Democrático de Direito, isto é, um Estado ${ }^{3}$ que, nos termos de uma Constituição, permite a participação do Povo na política, quer de maneira direta (voto, plebiscito e referendo, e.g.), quer de maneira indireta (por representação). Tem por base a democracia e por finalidade garantir direitos e promover o bem-estar e desenvolvimento sociais.

Todavia, nem sempre os paradigmas de Estado de Direito foram adotados pelos Estados. Muito antes do surgimento do primeiro paradigma, imperou a ideia hobbesiana de Estado como um ser onipotente e onipresente, um Leviatã, composto por muitos indivíduos que abdicaram de seus próprios poderes e liberdades em favor do Estado, a fim de receberem, em troca, proteção, resolução interna de conflitos e meios para alcançar o bem-comum. Ocorre que, sob essa ideia, legitimou-se a concentração das funções estatais nas mãos dos monarcas ou de grupos aristocráticos.

Como há de ser analisado mais adiante, o mundo antigo já conhecia algumas particularidades de cada função estatal, porém somente com a teoria clássica do barão de Montesquieu os cidadãos, então subjugados pelo grande Leviatã, conquistaram, por meio de revoluções, "rédeas" para domar esse grande Ser fictício - o Estado.

O rompimento com o absolutismo trouxe a vedação, para os Estados de Direito, à cumulação de todas as funções do Estado nas mãos de um único regente (ou um único órgão), uma vez que representa(ria) um risco à continuação do recém-conquistado regime democrático de governo, após séculos em que o mundo esteve sob períodos de prevalência das autocracias.

Ressalta-se que, apesar do termo "separação de poderes", é correto esclarecer que o poder do Estado é uno e que, por esta razão, o que de fato ocorre é a divisão das funções do Estado em órgãos independentes e harmônicos. Por esta razão, o verdadeiro significado da "separação de poderes" é a existência de "muitos órgãos exercendo o poder soberano do Estado, mas a unidade do poder não se quebra por tal circunstância” (DALLARI, 2013, p. 214-215).

Ao longo da história da República Pátria, desde o golpe militar de 15 de novembro 1889, que estabeleceu a República da Espada ${ }^{4}$ (1889 - 1894), o Brasil, por longos períodos, esteve subordinado pelo senhorio ditatorial, despido da liberdade ${ }^{5}$ e da verdadeira democracia ${ }^{6}$. Desta feita, a importância dada pelo Constituinte Originário ao princípio da separação dos

\footnotetext{
${ }^{3}$ Para o ilustre professor Dalmo de Abreu Dallari, “se poderá conceituar o Estado como a ordem jurídica soberana que tem por fim o bem comum de um povo situado em determinado território" (2013, p. 122), trazendo como elementos básicos para a existência de um Estado: 1) Soberania; 2) Povo; e 3) Território.

${ }^{4}$ Nome dado ao período em que a Primeira República, ou República-Velha, foi governada pelos Marechais Manuel Deodoro da Fonseca (1889-1891) e Floriano Vieira Peixoto (1891-1894).

${ }^{5}$ O Decreto n. ${ }^{\circ} 295$, de 29 de março de 1.890, feriu à liberdade de imprensa, sob argumento de "excepcionalidade", qualificando como praticantes de "crimes de conspiração contra a República e seu governo, aplicando-lhe as penas militares de sedição" (Decreto 85-A, de 23 de dezembro de 1.889) todos aqueles que violassem-no.

${ }^{6}$ Vide "voto de cabresto", Era Vargas e Ditadura Militar.
} 
poderes se dá pela razão de o Brasil ter vivenciado, empiricamente, os malefícios da sobreposição de um dos Poderes para com os demais, bem como na concentração de funções estatais nas mãos de um só indivíduo.

Neste tear, o artigo buscará tecer, com fios doutrinários, jurisprudenciais e de reconstruções históricas, um estudo a respeito de um dos princípios responsáveis por controlar a onipotência estatal - princípio da Separação dos Poderes -, procurando demonstrar sua importância para a manutenção da democracia.

No segundo capítulo deste trabalho analisar-se-á, de maneira breve, o surgimento da separação dos poderes da Idade Antiga à Modernidade, a partir do profeta Bíblico Isaías (VII a.C.) e do filósofo macedônico Aristóteles (IV a.C.) até chegar ao barão de Montesquieu. No capítulo subsequente, apresentar-se-á o surgimento dos paradigmas de Estado de Direito, buscando analisar a evolução da atuação do Poder Judiciário em cada um deles, e os problemas decorrentes da sobreposição de um dos poderes. Antecedendo a conclusão, será estudada a discussão que gira em torno do Poder Judiciário há alguns anos, isto é, ativismo judicial.

\section{ORIGENS DA SEPARAÇÃO DOS PODERES}

\subsection{DA ANTIGUIDADE}

No século VII a.C., no livro homônimo do judeu Yeshayahu ben Amotz $\mathrm{Ha}^{\text {Navi }}{ }^{7}$ (Isaías, capítulo 33, versículo 22 in ALMEIDA, 2016, p. 755) vislumbra-se o conhecimento da distinção entre cada função estatal, quando afirmou que "o SENHOR é o nosso juiz; o SENHOR é o nosso legislador; o SENHOR é o nosso rei...” (g.n.).

Ressalta-se que, no Reino de Judá, onde viveu o profeta, não havia aplicação da separação dos poderes nos moldes da tripartição clássica do Barão de Montesquieu. Todavia, apesar de concentrá-los todos em Deus, o fato de o escritor ter atribuído a Deus cada função de maneira separada demonstra que já havia uma noção da distinção entre elas.

Já no século IV a.C., em A Política, o macedônico Aristóteles (2010, p. 170), entendia que:

Toda Cidade tem três elementos (...). A primeira dessas partes concerne à deliberação sobre os assuntos públicos; a segunda, às magistraturas: qual deve ser instituída, qual deve ter sua autoridade específica e como os magistrados devem ser escolhidos; por último, relaciona-se a como de ser o poder judiciário.

Numa Dinis Fustel de Coulanges (1830-1889), em sua primorosa obra A Cidade Antiga, de 1864, de minuciosa pesquisa a respeito da cultura e política dos povos antigos, mais precisamente os hindus, gregos e romanos, dedicou a maior parte de sua obra ao estudo destes

\footnotetext{
${ }^{7}$ Profeta Isaías, filho de Amós.
} 
dois últimos povos. Demonstrou que o pater familias detinha todo o poder sobre sua familia, isto é, cada pater era soberano de seu próprio núcleo familiar. Das familias ${ }^{8}$ decorreram grupos organizacionais maiores, como as gentes, cúrias e as tribos, até formarem as cidades, que mantiveram estrutura semelhante à que existira nas familias.

Roma, o Sol do mundo ocidental antigo, foi a mais influente das cidades da Antiguidade, tendo exercido extenso domínio sobre grande parte daquele período. O direito desenvolvido pelos romanos, tido como base doutrinária e legal ainda na atualidade, foi concebido pela religião familiar, alimentado por séculos de mudanças sociais significativas, tendo presenciado tanto monarquia quanto república, bem como aristocracia e democracia, para, no fim, tornar-se um império personificado na figura dos césares. No césar encontravamse as funções estatais, que lhe conferiram status divino 9 .

\subsection{IDADE MÉDIA}

Centralizado no Império Romano do Ocidente, em 476 d.C., o mundo ocidental presenciou a destituição de Rômulo Augusto e, consequentemente, a queda de Roma. Assim, fragmentou-se todo este Império em reinos e nações sob domínio dos povos "bárbaros" (de cultura não greco-romana). Paulatinamente, surge o Feudalismo.

Apesar da queda do mais poderoso império do mundo Antigo, sua derradeira religião oficial e herdeira, o Cristianismo, expandiu-se e espalhou-se entre os mais diversos povos, exercendo sobre eles autoridade que, com o passar dos séculos, foi aumentando. No ano de 1215, a Europa ocidental voltava-se para a Igreja Católica Apostólica Romana, que se repousava soberana no trono romano, laureada com os louros do antigo império. Com o aumento da influência da Igreja Romana na política, apesar do poder "absoluto" que detinham os reis, o rei inglês João (John Lackland, ou João Sem-Terra) viu sua autoridade ser ameaçada pelas reivindicações dos barões e dos bispos da Inglaterra. Aos 10 de junho do referido ano, o rei assinou a Magna Carta Libertatum seu Concordiam inter regem Johannen et barones pro concessione libertatum ecclesiae et regni angliae ${ }^{10}$.

Para Dalmo de Abreu Dallari (2013, p. 78):

... o advento da Magna Carta inicia um novo capítulo na história da Inglaterra e, mais especificamente, do absolutismo inglês, assim como do constitucionalismo (...).

\footnotetext{
8 Jean-Jacques Rousseau afirmou que a família seria "a mais antiga de todas as sociedades" sendo a "única [sociedade] natural", isto é, não sendo decorrente do contrato social (1762, ed. 2013, p. 18).

${ }^{9}$ A título exemplificativo, o primeiro imperador romano, César Augusto, adotou o nome "Imperator Caesar Divi Filius Augustus" ("Imperador César, filho Divino, Majestoso" - tradução livre).

10 “Grande Carta das Liberdades ou Concórdia entre o Rei João e os Barões para outorga das liberdades da Igreja e do Reino Inglês" (tradução livre).
} 
Uma das consequências da Magna Carta foi o início de um processo que resultaria na criação do Parlamento Britânico, cujo papel seria decisivo tanto no combate ao absolutismo quanto no desenvolvimento do constitucionalismo.

\subsection{DA MODERNIDADE}

Sobre o fim da Era Medieval, ensina Marcelo Galuppo (2002, p. 57) que:

A modernidade é uma época de profundas rupturas, uma época de descentramentos. O mundo medieval era um mundo centralizado na Terra, na Europa e na Igreja Católica Romana. Como aponta Hannah Arendt (1991:260), a utilização por Galileu da luneta para investigar o céu mostrando que a Terra não era o Centro do Universo, as Grandes Navegações mostrando que a Europa não era o centro da Terra e a Reforma Protestante fazendo que a Igreja Católica Romana perdesse a posição de centro da civilização ocidental são decisivas na mudança da visão de mundo.

As sociedades humanas foram constituídas a fim de proporcionar o necessário para a subsistência dos grupos que nelas se refugiaram. Todavia, o fato de buscar abrigo na Civitas não significou o fim dos problemas dos homens. As relações inter homini são, ainda na atualidade, mui complexas. Por esta razão, Thomas Hobbes ensinou que o Estado deveria estar personificado em um homem, o monarca, ou num conjunto de homens, uma assembleia, que exerceria de forma soberana os poderes que lhe fora confiado pelos cidadãos no contrato social.

No início deste período de mudanças, o florentino Nicolau Maquiavel ${ }^{11}$ (14691527) afirmou, em $O$ Príncipe (1513), ainda que sem os termos hoje adotados, que a França já possuía um Parlamento ${ }^{12}$ para deliberar a respeito de assuntos legislativos (1532, ed. 2007, p. 162), bem como, segundo Dallari, “o Executivo (o rei) e um Judiciário independente”.

Entrementes, na Inglaterra reinavam as dinastias Tudor e, posteriormente, Stuart. Esta última, foi influenciada pelo contratualista Thomas Hobbes (1588-1679), que no seu Magnum opus, Leviatã (1651), afirmou que a guerra dos homens contra os homens ${ }^{13}$ fazia parte da condição humana, de modo que, na Natureza (fora da Sociedade), nenhum homem estaria a salvo do outro se não houvesse concórdia e renúncia de poderes. Deste modo, legitimava-se a supremacia do monarca, uma vez que seu excesso de império era entendido como mister para sobrevivência dos próprios cidadãos. Estes, por sua vez, deveriam contentar-se "com a mesma liberdade que permite aos demais, na medida em que considerar tal decisão necessária à manutenção da paz e de sua própria defesa" (HOBBES, 1651, ed. 2014, p. 111).

Ainda, para o autor (1651, ed. 2014, p. 142):

A essência do Estado consiste nisso e pode ser assim definida: uma pessoa instituída, pelos atos de uma grande multidão, mediante pactos recíprocos uns com os outros,

\footnotetext{
11 Além de trazer o termo "Estado" (do latim status, i.e., "manter-se firme"), o autor ensinou que as leis são mecanismos de defesa tipicamente humanos, estando acima da brutalidade animalesca (1532, ed. 2007, p. 151).

12 Apesar de citar somente a França, o primeiro Parlamento surgiu na Inglaterra.

${ }^{13}$ Bellum omnium contra omnes.
} 
como autora, de modo a poder usar a força e os meios de todos, da maneira que achar conveniente, para assegurar a paz e a defesa comum.

Aos 30 de janeiro de 1649, o rei Charles I, da Escócia, Inglaterra e Irlanda, foi decapitado. Deste modo, a monarquia absolutista inglesa foi substituída pela Commonwealth of England, Ireland and Scotland ${ }^{14}$ (1649-1660). Posteriormente, a monarquia foi reestabelecida em Charles II. No entanto, em 1688 iniciou a revolução que destronaria definitivamente a dinastia Stuart, era a Revolução Gloriosa, terminada em 1689. Dela decorreu a Declaração de Direitos de 1689 (Bill of Rights of 1689), documento normativo em que o Parlamento limitou o poder dos comonarcas Guilherme de Orange e Maria II, após a deposição do Rei Jaime II. Tal declaração foi fundamental para a retirada das funções estatais das mãos dos monarcas britânicos. Abriu-se, assim, precedente para que Estados adotassem um modelo descentralizador e mais democrático de política.

O inglês John Locke (1632-1704), segundo BOTTALLO (2007, p. 35-36), teria desenvolvido "uma teoria de governo limitado através da qual buscava justificar o regime parlamentar britânico estabelecido após a Revolução Gloriosa” e, muito embora a referida teoria não tenha sido tão clara no que se refere à separação dos poderes, Locke foi de suma importância para a divisão das funções estatais, sendo possível encontrar nele alguns "alicerces fundamentais que, mais tarde, iriam servir de base para notável construção de Montesquieu”.

Em Do espírito das leis (1748), Charles-Louis de Secondat, barão de La Brède e de Montesquieu (1689-1755), sistematiza a célebre teoria da Separação dos Poderes, enfatizando a necessidade de um Estado, que preze pela liberdade, adotar a separação das funções do Poder:

\begin{abstract}
Quando, na mesma pessoa ou no mesmo corpo de magistratura, o poder legislativo está reunido ao poder executivo, não existe liberdade; porque se pode temer que o mesmo monarca ou o mesmo senado crie leis tirânicas para executá-las tiranicamente. Tampouco existe liberdade se o poder de julgar não for separado do poder legislativo e do executivo. Se estivesse unido ao poder legislativo, o poder sobre a vida e a liberdade dos cidadãos seria arbitrário, pois o juiz seria legislador. Se tivesse unido ao poder executivo, o juiz poderia ter a força de um opressor.

Tudo estaria perdido se o mesmo homem, ou o mesmo corpo dos principais, ou dos nobres, ou do povo exercesse os três poderes: o de fazer as leis, o de executar as resoluções públicas e o de julgar os crimes ou as querelas entre os particulares. (MONTESQUIEU, Livro XI, Capítulo VI).
\end{abstract}

Na França, entre 1643 e 1715, reinou soberano o "rei-Sol”, Luís XIV. O monarca

foi, sem sombra de dúvidas, um dos mais afamados, quiçá o maior, dos monarcas franceses. Conhecido pela frase "L'État c'est moi"15 (O Estado sou eu), tornou-se o ícone do modelo

\footnotetext{
${ }^{14}$ Há de ser ressaltado que entre 1653 e 1658 esteve no poder o Lorde Protetor Oliver Cromwell (1599-1658), sucedido por seu filho, Richard Cromwell (1626-1712), que exerceu a função do pai até 1659. Era a República Puritana.

15 Segundo DALLARI (2013, p. 97), a referida frase "foi falsamente atribuída a Luís XIV, tendo sida provavelmente por Voltaire. Essa frase apareceu na história, que seria fantasiosa, de que o rei teria comparecido ao Parlamento de Paris com roupas de caça, de botas e esporas e com o chicote na mão e ali, para deixar claro que o Parlamento não tinha o direito de interferir nos negócios do Estado" e "se tornou símbolo do absolutismo".
} 
absolutista. Assim caminhava a França no Absolutismo, diferente do modelo que havia sido observado por Maquiavel. Todavia tal modelo estava prestes a ser destronado para que a descentralização das funções estatais nas mãos de um só pudesse ser coroada.

O fim do século XVIII foi marcado por novas Revoluções. Na Declaração de direitos do bom povo da Virgínia, de 16 de junho de 1776, em seu art. $5^{\circ}$, houve, enfim, a positivação da teoria da tripartição dos poderes. Em 4 de julho do mesmo ano, as treze colônias inglesas declaravam sua independência, surgindo, alguns anos depois, os Estados Unidos da América, que, em 1787, criou a primeira Constituição escrita propriamente dita, consagrando os parâmetros da tripartição.

No ano de 1789 ocorre a Revolução Francesa, que derrubou a dinastia real Bourbon. Em 26 de agosto do mesmo ano, é editada a Declaração dos Direitos do Homem e do Cidadão, que previa, no art. $6^{\circ}$ que "Toda sociedade na qual a garantia dos direitos não seja assegurada, nem a separação dos poderes determinada, não tem Constituição”. A partir de então, a Separação de Poderes tornou-se requisito indispensável para existência da pedra angular dos Estados modernos: a Constituição.

\section{OS PARADIGMAS DO ESTADO DE DIREITO E A SEPARAÇÃO DOS PODERES}

O ilustre professor Menelick de Carvalho Netto (1999, p. 473-486), sob influência de Thomas Kuhn, afirmou que paradigma "possibilita explicar o desenvolvimento científico como um processo que se verifica mediante rupturas, através da tematização e explicitação de aspectos centrais dos grandes esquemas gerais de pré-compreensões e visões-de-mundo".

A doutrina clássica divide o Estado de Direito em três paradigmas: Estado Liberal (Burguês) de Direito, Estado Social (ou de Bem-Estar Social) de Direito e Estado Democrático de Direito. Cada qual relacionado com diferentes períodos da História recente da Humanidade e a conquista de gerações de Direito.

\subsection{ESTADO LIBERAL BURGUÊS}

O surgimento do Estado de Direito, da limitação das funções estatais nas mãos de uma única pessoa ou de um único grupo privilegiado e da noção de constituição, decorreu de inúmeros fatores, dentre os quais, já tratados rapidamente neste artigo, destacam-se as Revoluções Gloriosa (1689), Estadunidense (1776) e Francesa (1789). 
O grande brado da Revolução Francesa foi a frase "liberté, égalité, fraternité"16, que ecoou, primeiramente, pelo Ocidente, tendo inspirado povos de diversos países a lutarem pelos seus direitos. Em um mundo marcado por nítida divisão de castas, sob argumento, inclusive, de predestinação Divinal ${ }^{17}$, a ideia de todos serem cidadãos de direitos, gozando da mais pura liberdade, em que o Estado compromete-se a não ferir os direitos que ele mesmo lhes outorgou, era inovadora. Para CARVALHO NETTO (1999, p. 478):

Pela primeira vez na história pós-tribal, todos os membros da sociedade são, ou devem ser, proprietários, homens livres e, assim, igualmente sujeitos de direitos, capazes, até mesmo o mais humilde trabalhador braçal, de realizar atos jurídicos contratuais como o da compra e venda da força de trabalho.

Os primeiros direitos outorgados aos cidadãos, portanto, foram os individuais e de caráter negativo, que presavam, majoritariamente, pela liberdade dos indivíduos em relação ao Estado: direitos políticos e à propriedade, à liberdade e à igualdade (formal). Foram, de fato, responsáveis pelo aumento do comércio e, consequentemente, basilares para o fortalecimento da classe burguesa, que havia revolucionado a sociedade.

O Brasil, após a Independência, adotou, em 1824, a Separação dos Poderes em sua Constituição Imperial, outorgada por Sua Majestade Imperial, o Imperador Dom Pedro I do Brasil, o Libertador, que apropriou-se do Poder Constituinte Originário, gozando de prerrogativas ilimitadas para elaboração da Constituição. Todavia, o modelo de separação adotado foi a teoria do francês Henri-Benjamin Constant de Rebecque (1767-1830), que, diferente da tripartição do barão de Montesquieu, era quadripartite.

$\mathrm{O}$ art. 10 da Constituição Imperial proclamava que "os Poderes Politicos reconhecidos pela Constituição do Imperio do Brazil são quatro: o Poder Legislativo, o Poder Moderador, o Poder Executivo, e o Poder Judicial”.

Muito embora o art. $9^{\circ}$ afirmasse que "A Divisão, e harmonia dos Poderes Politicos é o principio conservador dos Direitos dos Cidadãos, e o mais seguro meio de fazer effectivas as garantias, que a Constituição offerece", havia uma sobreposição de Sua Majestade Imperial, na qual estavam personificados os Poderes Moderador e Executivo, sobre os demais Poderes (Legislativo ${ }^{18}$ e Judiciário). Por essas razões, o Império do Brazil não pode ser considerado um

\footnotetext{
${ }^{16}$ Isto é, "liberdade, igualdade e fraternidade" (tradução livre).

${ }^{17}$ Embora a nobreza estivesse sustentada pela Bíblia (mais precisamente na carta de Paulo aos Romanos, capítulo 13), é inegável que o Cristianismo quebrou os paradigmas da antiguidade ao anunciar que todos os homens seriam iguais a partir do momento de sua conversão à Fé (Conf. Carta de Paulo aos Colossenses, capítulo 3, versículo 11: “... Onde não há grego, nem judeu, (...) bárbaro, cita, servo ou livre; mas Cristo é tudo, e em todos.”).

${ }^{18}$ O Imperador, sob a égide da Constituição Imperial de 1824, poderia nomear membros para o Senado Imperial do Brasil. Ademais, nos termos do art. 46 da referida Constituição, ao completarem vinte e cinco (25) anos, os príncipes da Casa Imperial do Brasil seriam "Senadores por Direito". A Princesa Imperial Dona Isabel, $a$ Redentora, a título de conhecimento, foi, portanto, a primeira Senadora do Brasil, muito embora não tenha subido ao cargo por meio do voto popular.
} 
Estado de Direito, muito embora Sua Majestade Imperial, o Imperador Dom Pedro II do Brasil, o Magnânimo, não tenha atuado na plenitude de suas atribuições. O paradigma de Estado Liberal surgiu pela primeira vez no Brasil em 1891, por meio do advento da Constituição Federal dos Estados Unidos do Brasil ${ }^{19}$.

O Estado Liberal depositou-se grande confiança no Poder Legislativo, cuja atuação, derivada da volonté générale ${ }^{20}$, consistia em editar leis que, consequentemente, eram responsáveis pela limitação na liberdade dos indivíduos. Um maiores direitos no paradigma de Estado Liberal de Direito era a liberdade, de modo que à medida em que se elaborava leis, mais o direito à liberdade era mitigado. Desta feita, somente o Legislativo tinha a possibilidade de promover tal mitigação. Era um “Estado mínimo". Por conseguinte, ao Poder Judiciário (bem como ao Executivo) foi concedido, meramente, o papel de bouche de $l a l o i^{21}$, de forma em que exercia puramente uma atividade mecânica (CARVALHO NETTO, 1999, p. 479).

Muito embora estivessem em voga os direitos anteriormente citados, esse período, de acordo com CARVALHO NETTO (1999, p. 479), ficou conhecido por "fundamentar as práticas sociais (...) de maior exploração do homem pelo homem (...), possibilitando um acúmulo de capital jamais visto e as revoluções industriais”.

\subsection{ESTADO SOCIAL (OU DE BEM-ESTAR SOCIAL) DE DIREITO}

Da exploração humana decorreu grande abismo de desigualdade social. Em 1848 foi publicado $O$ manifesto comunista, pelos alemães Friederich Engels e Karl Hendrich Marx. A obra serviu de base para movimentos comunistas, sindicalistas e socialistas em todo o mundo.

Com a eclosão da Primeira Guerra Mundial (1914-1918), o Estado Liberal, já em crise, estava em declínio. Sob influência do comunismo, liderados por Vladimir Ilyich Ulyanov (1870-1924), Lênin, surge a Revolução Russa (1917), da qual emergiu a União das Repúblicas Socialistas Soviéticas (1918-1992).

O Estado de Bem-Estar Social (Welfare State) tem início quando os direitos de segunda geração, ou direitos sociais, passaram a ser garantidos por Constituições. As primeiras Constituições a garanti-los foram as Constituições Mexicana (1917), de Weimar

\footnotetext{
${ }^{19}$ Com o golpe militar que estabeleceu a Primeira República Brasileira o Estado Brasileiro passou a adotar uma nova Carta Constitucional e, consequentemente, a partir de 1891 passou a vigorar o modelo da tripartição dos poderes, inspirado na Carta Constitucional Estadunidense.

20 "Vontade geral" (tradução livre).

21 "Boca da Lei" (tradução livre). Isto é, o magistrado estava preso à literalidade da Lei. No Brasil, um exemplo repousa no Habeas Corpus n. ${ }^{\circ}$ 1974, julgado em 1903. Na ocasião, o Ministro João Barbalho, do Supremo Tribunal Federal, entendeu que o fato de a Constituição de 1891 vedar somente o banimento judicial (art. 72, § 20) o banimento da Família Imperial não estaria revogado, pelo fato de ter decorrido do Decreto n. ${ }^{\circ} 78-\mathrm{A} / 1889$, estando somente o Congresso competente para revogá-lo.
} 
(1919) e a Austríaca (1920). Marcado pelas conquistas por direitos sociais, neste paradigma a igualdade de fato ${ }^{22}$ foi o alvo a ser atingido, uma vez que os direitos civis e políticos já haviam sido conquistados na primeira geração de direitos, no paradigma anterior. Deste modo, o Estado, que até então era mínimo e deveria manter-se longe da liberdade dos cidadãos, passou a interferir de forma mais significativa na vida dos indivíduos.

No Brasil, com a subida de Getúlio Dornelles Vargas (1882-1954) à presidência da República Brasileira, na década de 1930, inaugurou-se o paradigma de Estado Social através da nova Constituição, em 1934 (dois anos após a Revolução Constitucionalista de 1932). Segundo RUSSO (2014, p. 20), "foi a primeira Constituição a trazer um capítulo sobre a ordem econômica e social, inspirando-se na Constituição de Weimar, criando a Justiça do Trabalho", além de conter "normas sobre a família, educação e cultura". Em suma, o Estado do Bem-Estar Social atribuiu para si vasta obrigação em proporcionar melhor padrão de vida àqueles que, segundo CARVALHO NETTO, eram, econômica e socialmente, mais fracos (1999, p. 480).

As mudanças também refletiram nas atribuições conferidas ao Poder Judiciário. Conforme lição de CARVALHO NETTO (1999, p. 481), o papel do Poder Judiciário deixou de ser meramente mecânico em razão de demandar maior sofisticação na hermenêutica jurídica, "capazes de emancipar o sentido da lei da vontade subjetiva do legislador na direção da vontade objetiva da própria lei, profundamente inserida nas diretrizes de materialização do Direito que a mesma prefigura, mergulhada na dinâmica das necessidades dos programas e tarefas sociais".

Muito embora ocorresse um refinamento no papel no Judiciário, tendo recebido vigor em seu corpo outrora meramente autômato, a Constituição de 1937, em seu art. 73, com redação modificada pela Lei Constitucional n. ${ }^{\circ} 9$ de 1945, dizia que “o Presidente da República, autoridade suprema do Estado, dirige a política interna e externa, promove ou orienta a política legislativa de interesse nacional e superintende a Administração do País” (g.n.). Aqui, claramente, o princípio da Separação dos Poderes, inspirado pela teoria clássica do barão de Montesquieu, foi vilipendiado pela sobreposição do Poder Executivo.

Sob esse paradigma de Estado de Direito, a Humanidade assistiu à busca pela concretização (ou "materialização", termo adotado por Carvalho Netto in 1999, p. 480) dos direitos formais, legados pelo Estado Liberal, bem como o surgimento da Social Democracia. Todavia, testemunhou, também, o surgimento de ditadores como Franco, na Espanha, Hitler, na Alemanha, Mussolini, na Itália, Salazar, em Portugal, Stálin, na URSS e Vargas, no Brasil,

\footnotetext{
${ }^{22}$ Afirmou Rui Barbosa de Oliveira que "a regra da igualdade não consiste senão em quinhoar desigualmente aos desiguais, na medida em que se desigualam. (...) Tratar com desigualdade a iguais, ou a desiguais com igualdade, seria desigualdade flagrante, e não igualdade real." (1920, ed. 1997, p. 26).
} 
além dos crimes ocorridos na Segunda Guerra Mundial, dos quais destacam-se o Holocausto e as explosões das bombas atômicas em Hiroshima e Nagasaqui. As juristas Camila Silva NICÁCIO e Renata Camilo de OLIVEIRA (2002, p. 63) também afirmam o predomínio inicial do autoritarismo neste paradigma:

[O paradigma do Estado Social] se iniciou predominantemente autoritário, como se percebe na instauração da República de Weimar, na Alemanha, ou na Ditadura de Vargas, no Brasil, de tal forma que, com ele [i.e., com esse paradigma], pôs-se fim aos fundamentos jurídico-constitucionais nos quais se apoiava a autarquia do direito privado.

\subsection{ESTADO DEMOCRÁTICO DE DIREITO E CONSTITUIÇÃO DE 1988}

De acordo com NICÁCIO e OLIVEIRA (2002, p. 68):

Com o final da Segunda Guerra Mundial, o paradigma do Estado Social começa a ser questionado. Entretanto, é somente na década de 70, com a crise econômica, que a inadequabilidade desse modelo manifesta-se em toda sua dimensão, levando a um questionamento da racionalidade objetivista dos tecnocratas, do planejamento econômico, bem como da oposição antiética entre técnica e política, que acabaram transformando o Estado em uma empresa acima de outras empresas. [Fazem referência a CARVALHO NETTO, 1997, p. 481]

Para CARVALHO NETTO (1999, p. 481), tendo as sociedades se tornado "hipercomplexas" em razão da "era da informação ou pós-industrial", o Estado que havia se tornado uma "empresa acima de outras empresas" passou a abrir-se também para a terceira geração de direitos, "os chamados interesses ou direitos difusos, que compreendem os direitos ambientais, do consumidor e da criança, dentre outros", havendo, assim, tanto acréscimo ao rol de direitos quanto reinterpretação dos direitos de primeira e segunda gerações.

Com o término da Ditadura Militar (1964-1985), a fim de adequar-se à nova realidade social, a Sexta República invocou o Poder Constituinte Originário ${ }^{23}$, dando origem à sétima Constituição Brasileira, a Constituição Cidadã, promulgada em 5 de outubro de 1988. Neste contexto, BARROSO (2009, p. 19) ressalta como a Constituição de 1988 foi mister para que o Poder Judiciário viesse a ser, de fato, um "poder político" [sic]. Afirma, ainda, que o advento da "redemocratização" "fortaleceu e expandiu o Poder Judiciário", fazendo-o recuperar as "garantias da magistratura", deixando de ser um mero "departamento técnico-especializado".

Para HOFFMAM, CAVALHEIRO e NASCIMENTO (2011, p. 87), o Estado Social no Brasil foi responsável por prometer direitos à população que não pôde cumprir. Deste modo, o novo paradigma de Estado de Direito incumbiu o magistrado de concretizar as promessas constitucionais.

\footnotetext{
${ }^{23}$ À Assembleia Constituinte de 1987-1988, eleita em 1986, coube a honorável incumbência de elaborar a
} Constituição que serviria de sustentáculo de todo o edifício democrático que estava a ser erguido. 
O Constituinte Originário também prezou pela preservação da democracia conquistada, razão pela qual tornou a Separação dos Poderes cláusula pétrea, pela força do art. 60, $\S 4^{\circ}$, inciso III, da Carta Constitucional. O modelo de Separação dos Poderes pôde, de fato, ser tripartite, isto é, não havendo uma sobreposição de um Poder sobre os demais, como ocorreu nas ditaduras, em que o Poder Executivo deteve poder de editar normas legais e outorgar Constituição (e.g. Constituição Brasileira de 1937). Cabe destacar que a Constituição Cidadã da República Nova garantiu a cada Poder o exercício de funções típicas e atípicas. No caso do Poder Judiciário, além da função típica jurisdicional, possui constitucionalmente funções administrativas (no que se refere à administração interna dos órgãos jurisdicionais, podendo-se citar, como exemplo, a concessão de férias aos membros e servidores do Poder Judiciário) e legislativas (o fato de poder os tribunais elaborarem seus próprios regimentos, previsto na Constituição, é um dos exemplos do exercício desta função).

Toda a estrutura do corpo político estatal formado pela Carta Republicana visou a tornálo longevo, vigoroso e eficaz, de maneira que trouxe um rol muito maior de direitos aos cidadãos do que a Quinta República. Este rol, por mais singelo que possa parecer, além de ser ampliado, passou a habitar o início da Constituição, isto é, antes de tratar da estrutura do Estado. Buscou a Carta Constitucional frisar que do povo que emana todo o Poder, razão pela qual garantiu-lhe com direitos cobertos com a roupagem da dignidade da pessoa humana.

\section{HARMONIA ENTRE OS PODERES: ATUAÇÃO DO SUPREMO TRIBUNAL FEDERAL NO ESTADO DEMOCRÁTICO DE DIREITO BRASILEIRO}

No Estado Democrático de Direito brasileiro, a Constituição aumentou as atribuições do Poder Judiciário, de forma que, gradativamente, este Poder, especialmente em se tratando de seu órgão de cúpula - Supremo Tribunal Federal -, veio a tornar-se um dos protagonistas no palco da política nacional.

Para tanto, neste paradigma, ao magistrado não é mais reservado o papel de bouche de la loi, devendo analisar o caso concreto, observando a singularidade do caso e suas particularidades, valendo-se de toda a estrutura do Direito, sem generalidades, necessitando observar os princípios constitucionais, que também fazem parte dessa estrutura. Deste modo, o ícone de "Justiça Cega" tornou-se incompatível com o Estado Democrático de Direito, haja vista que exige-se do magistrado uma aplicação adequada nos casos que vierem a ser por ele julgados. Afirma CARVALHO NETTO (1999, p. 486) que: 
... sob as exigências da hermenêutica constitucional ínsita ao paradigma do Estado Democrático de Direito, requer-se do aplicador do Direito que tenha claro a complexidade de sua tarefa de intérprete de textos e equivalentes a texto, que jamais a veja como algo mecânico, sob pena de se dar curso a uma insensibilidade, uma cegueira, já não mais compatível com a Constituição que temos e com a doutrina e jurisprudência constitucionais que a história nos incumbe hoje a produzir. (g.n.)

\subsection{DA APLICABILIDADE DAS NORMAS CONSTITUCIONAIS}

O professor José Afonso da Silva (1993, p. 10-11), quanto à aplicabilidade das normas constitucionais, dividiu as normas da Constituição em três espécies:

a) Normas de eficácia plena, "são aquelas que, desde a entrada em vigor da Constituição, produzem ou têm a possibilidade de produzir todos os efeitos essenciais, relativamente aos interesses, comportamentos e situações, que o legislador constituinte, direta e normativamente, quis regular". Têm, portanto, aplicabilidade imediata;

b) Normas de eficácia contida, são "aquelas em que o constituinte regulou suficientemente os interesses relativos a determinada matéria, mas deixou margem à atuação restritiva da competência discricionário do Poder Público, nos termos que a lei estabelecer ou nos termos de conceitos gerais nelas enunciados..."; e

c) Normas de eficácia limitada, que "são todas as que dependem de uma providência ulterior (lei integrativa, processo especial, etc.) que the compete a eficácia e disponha sobre sua aplicação". Estas subdividem-se em:

a. Declaratórias de princípios institutivos ou organizativos, quando o Constituinte determina que leis disciplinem sobre determinada norma constituição a fim de que passe a produzir efeitos; e

b. Declaratórias de princípios programáticos, sendo aquelas que tratam de uma meta (ou "princípio", segundo o autor) a ser cumprida por um órgão do Poder Público, "visando à realização dos fins sociais do Estado".

\subsection{CONTROLE DE CONSTITUCIONALIDADE E INCONSTITUCIONALIDADE POR OMISSÃO}

A Constituição de $1920^{24}$ da Primeira República Austríaca (1919-1938) instituiu,

24 Vide art. 89 da Constituição da Áustria de 1920. Disponível (inglês) em: https://www.constituteproject.org/constitution/Austria_2013?lang=en. Acesso em 27 ago. 2018. 
pela primeira vez, um Tribunal Constitucional (Verfassungsgerichtshof), que, segundo MORAES (2016, p. 765), exerce, com exclusividade, o "controle judicial de constitucionalidade, em oposição ao consagrado judicial rewiew norte-americano, distribuído por todos os juízes e tribunais”. Este último é o chamado controle difuso de constitucionalidade, decorrente da decisão de John Marshall (1755-1835), Chefe de Justiça dos Estados Unidos da América entre 1801 e 1835, no case Madison vs. Marbury, enquanto que o primeiro trata do controle concentrado de constitucionalidade, cujo criador foi o austríaco Hans Kelsen (18811973), em sua Teoria Pura do Direito.

Um Tribunal Constitucional terá, nas palavras de KELSEN (1934, ed. 1985 in MORAES, 2016, P. 765), “competência para anular a validade da lei reconhecida como inconstitucional não só em relação a um caso concreto, mas em relação a todos os casos que a lei se refira", salientando que até a anulação da lei tida por inconstitucional esta continuará produzindo efeitos.

O Supremo Tribunal Federal destaca-se na Jurisdição Constitucional Brasileira, uma vez que o Brasil adotou ambos os modelos de controle de constitucionalidade. Ao Guardião da Constituição foram outorgados o poder de ter a última palavra no controle difuso (de exercício facultado a qualquer juiz ou tribunal, nos casos concretos) e a exclusividade na competência de exercer o controle concentrado de constitucionalidade de normas. Ainda, além de consagrar mecanismos para o controle de leis e atos normativos inconstitucionais, a Constituição Republicana de 1988 inovou a história do ordenamento jurídico brasileiro ao criar dois mecanismos para impugnar a inconstitucionalidade por omissão, isto é, a inação do Poder competente frente à determinação constitucional para que este torne eficaz à norma constitucional de eficácia limitada: o mandado de injunção e a ação direta de inconstitucionalidade por omissão ${ }^{25}$.

A Ação Direta de Inconstitucionalidade por Omissão (A.D.O. ou A.D.In. por omissão) está prevista no art. 103, §2º da Constituição da República. Só poderá ser ajuizada, no Supremo Tribunal Federal, pelos mesmos legitimados constitucionais para ajuizar uma Ação Direta de Inconstitucionalidade (A.D.I. ou A.D.In.), nos termos dos artigos 103 da Constituição Federal e 12-A da Lei n. 9.868 de 1999.

Há de se ressaltar que, segundo o Ministro Relator da ADO n. ${ }^{\circ}$ 24/DF, Dias Toffoli,

\footnotetext{
25 A Constituição da República Portuguesa de 1974, trouxe, em seu art. 283ª ", "inconstitucionalidade por omissão". Tal dispositivo serviu de inspiração para o Constituinte pátrio.
} 
ao citar o voto do Ministro Gilmar Mendes na ADI n. ${ }^{\circ} 3.682 / \mathrm{MT}$, também a inertia deliberandi $^{26}$ configura omissão legislativa, que, como tal fato inconstitucional, enseja cabimento para ajuizamento da ação.

O Mandado de Injunção, por sua vez, encontra-se previsto no art. $5^{\circ}$, LXXI, da Carta Constitucional de 1988 , e será concedido ao cidadão 27 "sempre que a falta de norma regulamentadora torne inviável o exercício dos direitos e liberdades constitucionais e das prerrogativas inerentes à nacionalidade, à soberania e à cidadania". Assim como a ADO, será de competência do Supremo Tribunal Federal, nos casos previstos no art. 102, I, q, da Constituição da República.

Para LENZA (2017, p. 1.136), quanto aos efeitos da decisão judicial, há três posições:

1. Posição concretista direta: para esta posição, "independente de atuação do órgão omisso", o Poder Judiciário "concretizará" os direitos diretamente através de decisão judicial que poderá produzir efeitos: 1) erga omnes (para todos); 2) "para um grupo, classe ou categoria de pessoas (coletivo)"; ou 3) individual, isto é, para "o impetrante, pessoa natural ou jurídica”.

2. Posição concretista intermediária: para esta, caberá ao Judiciário não só cientificar o órgão omisso, como também dar-lhe prazo para que supra a inconstitucional omissão. Findo o prazo, o próprio Judiciário tomará medidas a fim fazer com que a norma de eficácia limitada possa produzir efeitos sobre: 1) todos; 2) um grupo de indivíduos; ou 3) um indivíduo.

3. Posição não concretista: nesta corrente é incumbido ao magistrado somente dar ciência ao órgão omisso.

Assim, o Egrégio Supremo Tribunal Federal, inicialmente e de maneira tímida, adotou a posição não concretista. Para MORAES (2016, p. 190), sobre a posição inicial do STF no que se refere às decisões judiciais nos julgamentos dos mandados de injunção, observa que

\footnotetext{
${ }^{26}$ Por inertia deliberandi entende-se quando a Constituição Federal (ou uma Emenda Constitucional, e.g. EC n. ${ }^{\circ}$ 15 de 1996) determina um prazo para edição de lei que torne eficaz a norma constitucional limitada e, muito embora projeto de lei esteja em tramitação no Congresso Nacional, o prazo é desrespeitado.

${ }^{27}$ Pode configurar o polo ativo de referida ação: “pessoa física (pessoa natural), pessoa jurídica, Ministério Público, Partido Político com representação no Congresso Nacional, organização sindical, entidade de classe ou associação legalmente constituída e em funcionamento há pelo menos 1 (um) ano e Defensoria Pública" (FERNANDES, 2017, p. 626).
} 
a posição concretista geral:

... sempre foi pouco aceita na doutrina, pois como ressalvado pelo Ministro Moreira Alves, (...) [n]uma decisão com efeitos erga omnes estaria "o Supremo, o juiz ou tribunal que decidisse a injunção, ocupando a função do Poder Legislativo, o que seria claramente incompatível com o sistema de separação de poderes".

Entretanto, em 2007, no julgamento dos Mandados de Injunção de n. ${ }^{\circ}$ 670/ES e n. ${ }^{\circ}$ 708/DF, concluiu o Ministro Relator Gilmar Mendes que:

(...) tendo em vista as imperiosas balizas jurídico-políticas que demandam a concretização do direito de greve a todos os trabalhadores, o STF não pode se abster de reconhecer que, assim como o controle judicial deve incidir sobre a atividade do legislador, é possível que a Corte Constitucional atue também nos casos de inatividade ou omissão do Legislativo.

(STF. MI 670/ES e MI 708/DF - Rel. Min. Gilmar Mendes, decisão: 25-10-2007).

A decisão ensejou a incidência de decisões de cunho ativista pela Suprema Corte, reconhecendo MORAES o "claro ativismo judicial" ao adotar "a posição concretista, tanto geral, quanto individual" (2016, p. 190). Estaria o Judiciário ferindo a Harmonia dos Poderes?

Recentemente, o Supremo Tribunal Federal, ao julgar a ADO n. ${ }^{\circ}$ 26/DF e MI n. ${ }^{\circ}$ 4733/DF, enquadrou "homofobia e transfobia como crimes de racismo ao reconhecer omissão legislativa"28. Segundo o sítio virtual da Corte, a maioria dos ministros votou "pelo enquadramento da homofobia e da transfobia como tipo penal definido na Lei do Racismo (Lei 7.716/1989) até que o Congresso Nacional edite lei sobre a matéria”. Os ministros Enrique Ricardo Lewandowski e José Antonio Dias Toffoli, em contrapartida, entenderam "que a conduta só pode ser punida mediante lei aprovada pelo Legislativo". Diante do episódio, apesar de ser há muito tempo necessária uma tipificação penal que puna a homofobia e a transfobia, a máxima romana nullum crimen nulla poena sine pravia lege $e^{29}$ foi constitucionalizada pelo art. $5^{\circ}$, inciso XXXIX, da Constituição Federal. Para o Ministro Lewandowski ${ }^{30}$, portanto:

A extensão do tipo penal para abarcar situações não especificamente tipificadas pela norma penal incriminadora parece-me atentar contra o princípio da reserva legal ${ }^{31}$, que constitui uma fundamental garantia dos cidadãos, que promove a segurança

\footnotetext{
${ }^{28}$ SUPREMO TRIBUNAL FEDERAL. STF enquadra homofobia e transfobia como crimes de racismo ao reconhecer omissão legislativa. NOTÍCIAS STF: Brasília, 2019. Disponível em: http://www.stf.jus.br/portal/cms/verNoticiaDetalhe.asp?idConteudo=414010\&caixaBusca=N. Acesso em 18 jul. 2019.

29 "não há crime sem lei anterior que o defina, nem pena sem prévia cominação legal” (trecho constitucional).

${ }^{30}$ Disponível em: http://www.stf.jus.br/arquivo/cms/noticiaNoticiaStf/anexo/ADO26votoRL.pdf. Acesso em 18 jul. 2019.

${ }^{31}$ Para GOMES e MAZZUOLI (2008 apud LEWANDOWSKI, ADO 26/DF, p. 19) "no âmbito do Direito Penal incriminador, o que vale é o princípio da reserva legal, ou seja, só o Parlamento, exclusivamente, pode aprovar crimes e penas. Dentre as garantias que emanam do princípio da legalidade, acham-se a reserva legal (só o Parlamento pode legislar sobre o Direito Penal incriminador) e a anterioridade ('lex populi' e 'lex praevia', respectivamente). Lei não aprovada pelo Parlamento não é válida (...).” (g.n.).
} 
jurídica de todos.

\subsection{JUDICIALIZAÇÃO, ATIVISMO JUDICIAL E HARMONIA ENTRE OS PODERES}

É mister, antes de tudo, diferenciar judicialização de ativismo judicial. Para o ilustre Ministro Luis Roberto Barroso, a judicialização seria a atuação do Poder Judiciário dentro dos moldes estabelecidos pela Constituição Federal, assim não configurando "um exercício deliberado de vontade política" (2009, p. 21). O ativismo judicial, por sua vez, seria uma forma proativa de interpretação "da Constituição, expandindo o seu sentido e alcance" (2009, p. 22). Ainda segundo o Ministro, o ativismo é instalado em "situações de retração do Poder Legislativo, (...) impedindo que as demandas sociais sejam atendidas de maneira efetiva". O Poder Judiciário, portanto, estaria agindo a fim de concretizar "valores e fins constitucionais, com maior interferência no espaço de atuação dos outros dois Poderes" (2009, p. 22). Para o Ministro (2009, p. 19-20), são três as causas da judicialização:

1) o advento da redemocratização foi responsável expansão do Poder Judiciário, que "aumentou a demanda por justiça na sociedade brasileira";

2) o fato de que "a Carta brasileira é analítica, ambiciosa, desconfiada do legislador", isso em virtude da existência de um rol extensivo de direitos por ela garantidos, bem como pelos mais diversos temas por ela disciplinados; e

3) "o sistema brasileiro de controle de constitucionalidade", que, para o autor, baseado na obra Jurisdição Constitucional (2005) do Ministro Gilmar Mendes, é "um dos mais abrangentes do mundo", isto pela razão dos mecanismos trazidos pelo Constituinte a fim de concretizar as normas constitucionais.

O Ministro Alexandre de Moraes relembra que, a priori, o ativismo judicial, no período em que o paradigma de Estado do Bem-Estar Social entrou em crise, esteve presente na Suprema Corte dos Estados Unidos da América, tendo sido responsável por encerrar a política dos "iguais, mas separados", dando "início ao fim da segregação dos Estados Unidos da América" (MORAES, 2016, p. 808). Sobre ativismo judicial, porém, Dworkin (p. 451, apud MORAES, 2016, p. 808) alertou que:

o ativismo é uma forma virulenta de pragmatismo jurídico. O juiz ativista ignoraria o texto da Constituição, a história de sua promulgação, as decisões anteriores da Suprema Corte que buscaram interpretá-la e as duradouras tradições de nossa cultura política. O ativista ignoraria tudo isso para impor a outros poderes do Estado o seu próprio ponto de vista sobre o que a justiça exige. (g.n.)

BARROSO (2009, p. 21) reconhece a existência da "judicialização", porém, ao negar que os Ministros do Supremo Tribunal Federal aspirem a criar um modelo "juriscêntrico", 
afirma que tal atuação "não decorreu de uma opção ideológica, filosófica ou metodológica da Corte. Limitou-se ela a cumprir, de modo estrito, o seu papel constitucional, em conformidade com o desenho institucional vigente." Conclui opinando "que o modelo tem nos servido bem". Muito embora o Ministro (2009, p. 32) também entenda ser a judicialização "um antibiótico poderoso", acredita que "em dose excessiva, há risco de se morrer da cura". Afirma, também, que "o problema brasileiro atual não é excesso de judicialização, mas escassez de boa política" e que a preocupação com o tema é "assustar-se com a assombração errada", fazendo referência aos Poderes Legislativo e Executivo, mais especialmente ao primeiro do que ao segundo (BARROSO, 2012, apud MAGIONI, 2016, p. 293).

A título exemplificativo, BARROSO (2009, p. 23) relembra situações em que o Guardião da Constituição adotou posição "claramente ativista": 1) não havendo previsão expressamente constitucional, o STF "declarou que a vaga do Congresso pertence ao partido político"; 2) onde, através de Súmula Vinculante (n. $\left.{ }^{\circ} 13\right)$, estendeu "a vedação do nepotismo aos Poderes Legislativo e Executivo" e configurou "uma conotação quase-normativa" pela razão de o Supremo haver julgado tão somente "um único caso" (g.n.) em contraposição a exigência do Constituinte Derivado Reformador de somente editar súmulas de caráter vinculante após "reiteradas decisões sobre matéria constitucional" (trecho do art. 103-A, caput, da Constituição Federal).

Para MAGIONI (2016, p. 293):

é inegável que tal atuação revela, também, certa usurpação política do Poder Judiciário, que passou a interferir na divisão orgânica dos três Poderes e causar um certo desequilíbrio democrático. Isso tudo, sem falar que tal atuação é temerária, em razão dos visíveis riscos de uma hegemonia judicial, uma ditadura de juízes. (g.n.)

Este artigo, por sua vez, alia-se ao pensamento esculpido por HOFFMAM,

CAVALHEIRO e NASCIMENTO (2011, p. 90), que consiste em afirmar que o paradigma atual de Estado Democrático de Direito carece de maior atuação do Poder Judiciário, a fim de que o Povo, fonte do Poder estatal, possa gozar dos direitos que já lhe foram garantidos. Afirmam que:

... não restam dúvidas de que o magistrado em terrae brasilis, deve ser sim, ativo, mas, sem ser ativista, ter discricionariedade para interpretar hermenêuticointegrativamente o direito, mas, sem ser arbitrário ou decisionista, ser sim, um juiz que (re) cria o direito, mas, não o cria a partir de um grau zero de significado, bem como, ser combativo e participativo, mas, sem extrapolar suas funções. Ou seja, pedese um juiz responsável, que cumpra os ditames constitucionais e, trabalhe na persecução de um verdadeiro Estado Democrático de Direito.

Conciliando os pensamentos de Mauro Cappelletti (1927-2004) e Ronald 
Dworkin $^{32}$ (1931-2013), HOFFMAM et alii (2011, p. 80) proclamam que o modelo ideal de magistrado será aquele que poderá concretizar o Ordenamento Jurídico através do princípio da discricionariedade, (re)criando o Direito, mas fazendo-o a partir de bases normativas e principiológicas já existentes, de forma prudente, cumprindo com a vontade da Constituição.

Outra discussão doutrinária gira em torno da legitimidade do Poder Judiciário em tomar decisões na esfera política, suprindo a inação legislativa e executiva. Tal discussão tem como ponto de partida o fato de que os membros dos Poderes Executivo e Legislativo são eleitos mediante o voto popular a fim de representar o Povo, o que não ocorre com os magistrados, que passam a compor o Poder Judiciário mediante concurso ou indicação do Chefe do Poder Executivo nos âmbitos Federal, Estaduais e Distrital. É o Ministro Barroso quem defende o Judiciário, ao afirmar que, pelo fato de todo o Poder emanar do Povo, e sendo o Poder Judiciário uma função do Estado detentor daquele Poder, estaria coberto com o manto da democracia e da representação da população. Todavia, a justificativa não põe uma pedra sobre a discussão.

A respeito da harmonia entre os Poderes, o barão de Montesquieu afirmou que "para que não se possa abusar do poder é preciso que, pela disposição das coisas, o poder freie o poder" (Livro XI, capítulo IV). Dessa forma, entende-se que a harmonia nada mais seria do que a comunhão entre os Poderes a fim de atingir um alvo comum, sem a sobreposição de qualquer um deles sobre os demais, mas havendo a possibilidade de um frear o outro no intuito de impedir excessos. Nesse sentido, SANTOS (1992, p. 215) entende que, em decorrência da harmonia e, também, da independência entre os Poderes, colaborariam entre si, de modo que cada qual auxiliaria e/ou corrigiria o outro no que lhe coubesse, onde "a independência e a harmonia geram a interdependência, que é, em suma, o conjunto das relações entre eles”.

Por fim, afirma MORAES (2016, p. 436) que:

Não existirá, pois, um Estado democrático de direito, sem que haja Poderes de Estado e Instituições, independentes e harmônicos entre si, bem como previsão de direitos fundamentais e instrumentos que possibilitem a fiscalização e a perpetuidade desses requisitos. Todos estes temas são de tal modo ligados que a derrocada de um, fatalmente, acarretará a supressão dos demais, como o retorno do arbítrio e da ditadura. (g.n.)

\section{CONSIDERAÇÕES FINAIS}

\footnotetext{
${ }^{32}$ Sendo, para Dworkin, o modelo adequado de juiz aquele em que o magistrado observaria os princípios por trás de cada regra, onde "a resposta correta dada de maneira a integrar coerentemente a prática jurídica assentada ao longo da história, ou (...) ao longo de uma tradição jurídico-decisória” (HOFFMAM et alii, 2011, p. 90).
} 
A problemática tratada neste artigo diz respeito do ativismo judicial, decorrente de atuações do Poder Judiciário que, iniciadas de maneira tímida, foram desbravando um caminho novo no território nacional. O comportamento proativo do Poder Judiciário seria nocivo à saúde e ao desenvolvimento da jovem democracia brasileira?

O Constituinte Originário, claramente inspirado pelo paradigma de Estado Democrático de Direito, tinha conhecimento de que a mera declaração de direitos fundamentais na Carta Suprema de uma Nação não seria suficiente para diminuir o abismo existente entre os mundos do SER e do DEVER-SER, isto é, o texto constitucional, por mais belo e fausto que pudesse ser, poderia não refletir a realidade. Por consequente, o artigo buscou refletir sobre o papel do Poder Judiciário na concretização de direitos e na construção de uma ponte entre o SER e o DEVER-SER. Para tanto, foi estudado o controle de constitucionalidade e as inovações constitucionais representadas pelo Mandado de Injunção e pela Ação Direta de Inconstitucionalidade por Omissão, mecanismos trazidos pelo Constituinte de maneira a impedir omissão inconstitucional legislativa (inclusive nos casos de inertia deliberandi) ou administrativa.

Constatou-se que, muito embora a atuação judiciária tenha garantido a efetivação de direitos constitucionais, o demasiado desempenho do Poder Judiciário no campo político de atuação dos outros Poderes configura ativismo judicial e, consequentemente, um risco para a sobrevivência da manceba República que surge da (re)conquista da democracia após décadas de alternâncias entre regimes democráticos e autocráticos (ditaduras). É notável que o princípio da Separação dos Poderes (a ser entendido como a divisão das funções estatais entre órgãos específicos, a fim de evitar uma concentração tipicamente ditatorial) não surgiu subitamente, não decorreu do ocaso ao alvorecer, tampouco de um devaneio, senão que adveio da quebra das mazelas medievais, do absolutismo e do fim dos privilégios das castas dominantes naquele período.

Uma vez que o Livro da História da Humanidade é escrito com as canetas das ações humanas, muito embora haja semelhanças em seus capítulos, cada capítulo, parágrafo ou linha da História é um evento único e singular, que só fica claro quando concluído, de modo que o futuro é sempre nebuloso. Apesar da impossibilidade científica de prever o futuro, a experiência histórica da justaposição de um dos Poderes sobre os demais e os dissabores dos regimes antidemocráticos - que feriram os filhos desta Pátria e macularam sua história - têm provado a existência de riscos para um Estado que tem por regime a democracia e, consequentemente, aos cidadãos que o compõem. Dessarte, a (re)conquistada democracia representa o bem mais 
precioso da Nação brasileira, razão pela qual manter a harmonia e independência dos Poderes é sinônimo de preservar o Estado Democrático de Direito.

\section{REFERÊNCIAS BIBLIOGRÁFICAS}

ALMEIDA, João Ferreira de (tradutor). Bíblia Sagrada: Edição Revista e Corrigida com Dicionário e Concordância. Barueri: Sociedade Bíblica do Brasil, 2016.

ARISTÓTELES. Política. Tradução Pedro Constantin Tolens. São Paulo: Editora Martin Claret, 2010.

ÁUSTRIA. Constituição Federal Austríaca. 1920.

BARBOSA, Rui. Oração aos Moços. 5. ed. Rio de Janeiro: Fundação Casa de Rui Barbosa, 1997.

BARROSO, Luís Roberto. Judicialização, ativismo judicial e legitimidade democrática. Anuario Iberoamericano de Justicia Constitucional. Num. 13, Madrid, p. 17-32, 2009.

BOTTALLO, Eduardo Domingos. Teoria da Divisão dos Poderes: antecedentes históricos e principais aspectos. Revista da Faculdade de Direito da Universidade de São Paulo, v. 102, p. 25-46, 2007.

BRASIL. Constituição da República Federativa do Brasil. 5 out. 1988.

Constituição Política do Imperio do Brazil. 25 mar. 1824.

Constituição dos Estados Unidos do Brasil. 10 nov. 1937.

Decreto 85-A. 23 dez. 1889.

Decreto 295. 29 mar. 1890.

Lei n. 9.868. 10 nov. 1999.
Lei n. 12.063. 27 out. 2009.

CAMPO, Gabriel Afonso. Poder moderador na obra de Constant e na Constituição de 1824: pena de morte e sua comutação e perdão entre os escravos brasileiros no século XIX. Estudios de Filosofía Práctica e Historia de las Ideas, v. 21, p. 1-19, 2019.

CARVALHO NETTO, Menelick de. Requisitos pragmáticos da interpretação jurídica sob o paradigma de Estado Democrático de Direito. Revista de Direito Comparado III. Belo Horizonte: Mandamentos, p. 473-486, 1999.

COULANGES, Numa Dinis Fustel de. A Cidade Antiga. Tradução Jean Melville. São Paulo: Editora Martin Claret, 2006.

DALLARI, Dalmo de Abreu. A Constituição na vida dos Povos: da Idade Média ao Século XXI. São Paulo: Editora Saraiva, 2013.

Elementos de teoria geral do Estado. 32. ed. São Paulo: Editora Saraiva, 2013.

ESTADOS UNIDOS DA AMÉRICA. Declaração de direitos do bom povo da Virgínia. 12 jun. 1776.

Constituição dos Estados Unidos da América. Ratificado em 21 de jun. de 1788.

FERNANDES, Bernardo Gonçalves. Curso de direito constitucional. 9. ed. Salvador: Editora Jus Podivm, 2017.

FRANÇA. Declaração dos Direitos do Homem e do Cidadão. 26 de ago. de 1789. 
GALUPPO, Marcelo Campos. Igualdade e diferença: Estado democrático de direito a partir do pensamento de Habermas. Belo Horizonte: Editora Mandamentos, 2002.

HOBBES, Thomas. Leviatã. Tradução Rosina D’Angina. São Paulo: Editora Martin Claret, 2014.

HOFFMAM, Fernando; CAVALHEIRO, Larissa N.; NASCIMENTO, Valéria R. do. Dworkin versus Cappelletti: Qual o modelo de juiz adequado ao Estado Democrático de Direito? Revista do Direito UNISC, Santa Cruz do Sul, n. 36, p. 80-94, 2011.

INGLATERRA. Declaração de Direitos. 16 dez. 1689.

LENZA, Pedro. Direito constitucional esquematizado. $21^{\mathrm{a}}$ ed. São Paulo: Editora Saraiva, 2017.

MAGIONI, Lucas Lobato. Judicialização e Ativismo Judicial na perspectiva do Estado Democrático de Direito. Raízes Jurídicas, v. 8, n. 1, Curitiba, p. 261-324, 2016.

MAQUIAVEL, Nicolau. O príncipe: comentários de Napoleão I e Cristina da Suécia. Tradutor Fulvio Lubisco. São Paulo: Editora Jardim dos Livros, 2007.
MONTESQUIEU, Charles-Louis de Secondat, barão de. Do espírito das leis. São Paulo: Editora Abril, 1973.

MORAES, Alexandre de. Direito constitucional. São Paulo: Editora Atlas, 2016.

NICÁCIO, Camila Silva; OLIVEIRA, Renata Camilo de. Os paradigmas da interpretação do Direito na modernidade. Revista do CAAP, v. 10, 2002, p. 57-80.

PORTUGAL. Constituição da República Portuguesa. 2 abr. 1976.

ROUSSEAU, Jean-Jacques. Do contrato social. Tradução Ana Resende. São Paulo: Editora Martin Claret, 2013.

RUSSO, Luciana. Direito Constitucional, 9. São Paulo: Editora Saraiva, 2014.

SANTOS, Márcia Walquiria Batista dos. Separação dos poderes: Evolução até a Constituição de 1988 - Considerações. Revista inf. Legisl. a. 29, n. 115, Brasília, 1992, p. 209-218.

SILVA, José Afonso da. Aplicabilidade das normas constitucionais. Revista Pensar, v. 2, n. 2, Fortaleza, p. 7-22, 1993.

SILVA, L. F. M. M. Mandado de Injunção 27 anos: História e Memória. Revista Jurídica da Procuradoria-Geral do Distrito Federal, v. 40, n. 1, Brasília, p. 201-218, 2015.

\section{ESTRANGEIRA BRIEF HISTORY OF THE PRINCIPLE OF THE SEPARATION OF THE POWERS IN THE PARADIGMS OF THE RULE OF LAW}

Cícero José Barbosa Nery Júnior

How to cite this article: NERY JÚNIOR, Cícero José Barbosa. Breve história do princípio da separação dos poderes nos paradigmas do Estado de direito. Revista de Ciências do Estado. Belo Horizonte: v. 5, n. 1, e14786. ISSN: 2525-8036. 
Abstract: the paradigm of the Rule of Law, with the purpose of realizing the rights provided for in the Constitution, entrusted to the Judiciary Power the honorable mission to give effect to constitutional rights. In this way, the leadership of this Power, the STF, has become one of the protagonists in the political stage of Brazil, which has raised doctrinal discussions and the public sphere about its legitimacy in acting proactively. Analyze, through historical reconstructions as to the origins of the principle of Separation of Powers and of the Democratic State of Law enshrined in the 1988 Brazilian Constitution, the risk that the juxtaposition of one of the Powers over the others represents for (re)conquered national democracy.

Keywords: Separation of the Powers; Rule of the Law; Juxtaposition of the Powers. 